University of Nebraska - Lincoln

DigitalCommons@University of Nebraska - Lincoln

Faculty Publications from the Harold W. Manter Laboratory of Parasitology

8-1993

\title{
Some Platyhelminths Inhabiting White-Throated Sparrows, Zonotrichia albicollis (Aves: Emberizidae: Emberizinae), from Algonquin Park, Ontario, Canada
}

\author{
Daniel R. Brooks \\ University of Toronto,dnlbrooks@gmail.com \\ Eric P. Hoberg \\ United States Department of Agriculture \\ Anne Houtman \\ University of Toronto
}

Follow this and additional works at: https://digitalcommons.unl.edu/parasitologyfacpubs

Part of the Parasitology Commons

Brooks, Daniel R.; Hoberg, Eric P.; and Houtman, Anne, "Some Platyhelminths Inhabiting White-Throated Sparrows, Zonotrichia albicollis (Aves: Emberizidae: Emberizinae), from Algonquin Park, Ontario, Canada" (1993). Faculty Publications from the Harold W. Manter Laboratory of Parasitology. 254.

https://digitalcommons.unl.edu/parasitologyfacpubs/254

This Article is brought to you for free and open access by the Parasitology, Harold W. Manter Laboratory of at DigitalCommons@University of Nebraska - Lincoln. It has been accepted for inclusion in Faculty Publications from the Harold W. Manter Laboratory of Parasitology by an authorized administrator of DigitalCommons@University of Nebraska - Lincoln. 


\section{RESEARCH NOTES}

J. Parasitol., 79(4), 1993, p. 610-612

(C) American Society of Parasitologists 1993

\section{Some Platyhelminths Inhabiting White-throated Sparrows, Zonotrichia albicollis (Aves: Emberizidae: Emberizinae), from Algonquin Park, On- tario, Canada}

Daniel R. Brooks, Eric P. Hoberg*, and Anne Houtman, Department of Zoology, University of Toronto, Toronto, Ontario, Canada M5S 1A1; and *Biosystematic Parasitology Laboratory, USDA, ARS, Beltsville, Maryland 20705

\begin{abstract}
Twenty-two of 26 white-throated sparrows, Zonotrichia albicollis, from Algonquin Park, Ontario, Canada, hosted 1 or 2 species of platyhelminths. One species of cestode and 3 of digeneans were collected. Anonchotaenia quiscali inhabited $50 \%$ of the sparrows. This is the third report of A. quiscali; $Z$. albicollis is a new host. Brachylecithum nanum inhabited $43 \%$, Zonorchis alveyi 15\%, and Prosthogonimus macrorchis $8 \%$ of the sparrows examined. Ontario is a new geographic distribution record for all 4 parasite species. The proportion of hosts infected with 2 species was not significantly different from expected based on single species prevalences, indicating that there is no competitive interaction among these species of parasites for access to the avian hosts.
\end{abstract}

The white-throated sparrow, Zonotrichia albicollis (Gmelin), has become an important model system for ecological and behavioral studies, as a result of studies documenting information about their mating system and breeding behavior (Knapton and Falls, 1983; Knapton et al., 1984; Kopachena, 1992), habitat preferences (Knapton and Falls, 1982), population structure (Thorneycroft, 1976; Knapton and Falls, 1983), singing behavior (Falls, 1969), and aggressive behavior (Lowther and Falls, 1968; Hailman, 1975; Ficken et al., 1978; Watt et al., 1984; Schwabl et al., 1988). As part of a long-term study of the behavioral ecology of $Z$. albicollis in Algonquin Park, Ontario, Canada, we collected parasites from 26 ( 16 males and 10 females) white-throated sparrows during 27-30 May 1991.

Birds were caught on territories at the beginning of the breeding season using mistnets. Captured birds were killed promptly with an overdose of anesthetic and dissected immediately. Helminths were collected alive, rinsed in saline, fixed with alcohol-formalin-acetic acid (digeneans were flattened with slight coverslip pressure if large and heat killed to relax them if small; cestodes were relaxed until moribund in cold saline), stored in $70 \%$ ethanol, stained with Mayer's hematoxylin and mounted in Canada balsam. Representative specimens of digeneans were deposited in the Harold W. Manter Laboratory, Division of Parasitology, University of Nebraska State Museum (HWML); specimens of cestodes were deposited in the U.S. National Museum Helminthological Collection, Beltsville, Maryland (USNM Helm. Coll.). We collected specimens of 1 species of cestode and 3 species of digeneans (Table I).

Anonchotaenia quiscali was originally described in common grackles, Quiscalus quiscali (Linnaeus) (reported as Quiscalus versicolor Vieillot) (Emberizidae: Icterinae) from Ohio (Rausch and Morgan, 1947). There appears to be only 1 subsequent record of this cestode, from red-winged blackbirds, Agelaius phoeniceus (Linnaeus), another member of Icterinae, also from Ohio (Stanley and Rabalais, 1971). This is the first recognized occurrence of $A$. quiscali in $Z$. albicollis, thus constituting a new host record and extending the range of known definitive hosts to 2 subfamilies of emberizids. This report also extends the known geographic distribution of the species, now known from Ohio and Ontario. Another species of Anonchotaenia, A. globata (von Linstow, 1879), a ubiquitous cestode inhabiting a wide variety of passerine birds (Schmidt, 1986), has been reported from $Z$. albicollis. Anonchotaenia globata can be distinguished from $A$. quiscali on the basis of 3 traits: A. globata has an average of 4 testes per proglottid, cirrus sacs averaging $79 \mu \mathrm{m}$ in length, and scolices averaging $760 \mu \mathrm{m}$ in diameter, whereas $A$. quiscali has an average of 8.5 testes per proglottid, cirrus sacs averaging $118 \mu \mathrm{m}$ in length, and scolices averaging $550 \mu \mathrm{m}$ in diameter. Specimens of $A$. quiscali all were gravid and had completely formed paruterine organs. Although Rausch and Morgan (1947) described 9 testes per proglottid, the specimens collected in this study exhibited variation in testes numbers. In counts from 8 strobila, the number of testes ranged from 5 to 10 per proglottid ( $\bar{x}=8 \pm 1.05, \mathrm{n}=222$ segments). Such variation is not inconsistent with that reported 
TABLE I. Information about site of infection, prevalence, and range of intensity for 4 species of helminths collected in Zonotrichia albicollis from Algonquin Park, Ontario, Canada.

\begin{tabular}{|c|c|c|c|c|}
\hline & $\begin{array}{l}\text { Site of } \\
\text { infection }\end{array}$ & Prevalence* & $\begin{array}{l}\text { Range of } \\
\text { intensity }\end{array}$ & $\begin{array}{l}\text { Specimens } \\
\text { deposited } \dagger\end{array}$ \\
\hline \multicolumn{5}{|l|}{ Eucestoda: Cyclophyllidea: Dilepididae } \\
\hline Anonchotaenia quiscali Rausch and Morgan, 1947 & $\begin{array}{l}\text { Entire } \\
\text { length of } \\
\text { intestine }\end{array}$ & $50 \%$ & $1-13$ & $\begin{array}{l}\text { USNM Helm. Coll. } \\
\text { nos. } 82201,82208\end{array}$ \\
\hline \multicolumn{5}{|l|}{ Digenea: Plagiorchiformes: Dicrocoeliidae } \\
\hline $\begin{array}{l}\text { Brachylecithum nanum Denton and Byrd, } 1951 \\
\text { Zonorchis alveyi (Martin and Gee, 1949) } \\
\text { Denton and Byrd, 1951 }\end{array}$ & $\begin{array}{l}\text { Liver } \\
\text { Gall bladder }\end{array}$ & $\begin{array}{l}43 \% \\
15 \%\end{array}$ & $\begin{array}{l}5-20 \\
1-25\end{array}$ & $\begin{array}{l}\text { HWML no. } 34096 \\
\text { HWML no. } 34097\end{array}$ \\
\hline \multicolumn{5}{|l|}{ Digenea: Plagiorchiformes: Prosthogonimidae } \\
\hline Prosthogonimus macrorchis Macy, 1934 & Oviducts & $8 \%$ & $3-22$ & HWML no. 34098 \\
\hline
\end{tabular}

for other species of Anonchotaenia by Mariaux (1991), for which distinction from otherwise similar taxa has been based largely on comparison of the mean number of testes per proglottid as determined from counts in a large number of segments. Aside from the numbers of testes, other mensural and structural characters in the cestodes collected in white-throated sparrows were consistent with the original description of $A$. quiscali; for example, in our specimens average cirrus sac length was $116 \mu \mathrm{m}$ and average scolex diameter was $525 \mu \mathrm{m}$, whereas Rausch and Morgan (1947) reported average values of $120 \mu \mathrm{m}$ and $580 \mu \mathrm{m}$, respectively.

Among the digeneans collected, Brachylecithum nanum was originally described in Z. albicollis, Zonotrichia leucophrys (Forster), and rufous-sided towhees, Pipilio erythrophthalmus (Linnaeus), from Georgia, North Carolina, Virginia, and Texas (Denton and Byrd, 1951), and it has been reported subsequently in the Florida scrub jay, Aphelocoma coerulescens (Bosc), from Florida (Kinsella, 1974) and Passerella sp. from Iowa (Ellis, 1963). This report extends the known geographic distribution of the species to Ontario. Prosthogonimus macrorchis occurs in a wide variety of wild and domestic avian hosts over a broad geographic range. Ellis (1963) reported Prosthogonimus sp. in Z. albicollis from Iowa, but this is apparently the first report specifically of $P$. macrorchis in Z. albicollis. Prosthogonimus macrorchis has been implicated in reduction of fecundity through interference with egg production (Schmidt and Roberts, 1989). In this study, 1 of the 2 sparrows infected with $P$. macrorchis had 3 worms and the other had 22 worms; in neither case was there any evident pathological change, but histological examination of the oviducts was not performed. Finally, Zonorchis alveyi is a common species in passerines; it has been reported in Z. albicollis in Georgia and Texas (where it is also known to inhabit $Z$. leucophrys [see Denton and Byrd, 1951]), and Manitoba (Hodasi, 1963). Within Canada, it has been reported in Zonotrichia iliaca (Morrem) (as Passerella iliaca) from Newfoundland (Jewer and Threlfall, 1978). Ontario is thus a new geographic distribution record.

Twenty-two $(84.6 \%)$ of the white-throated sparrows examined hosted at least 1 species of helminth. Eight (30.7\%) hosted 2 species of helminths and none hosted 3 or 4 species. The proportion of hosts infected with 2 species was not significantly different from the expected values based on single species prevalences $\left(\chi^{2}=0.095\right.$, $P=0.9999, \mathrm{df}=5$ ). This indicates that there is no competitive interaction among these species of parasites for access to the avian hosts. This is not surprising, given that each species occupies a different site in the definitive host. It is also possible that these data reflect differences in intermediate hosts as well, but the intermediate hosts for these species in Algonquin Park are unknown. Given the prevalences of the helminth species, our sample size does not reveal whether the absence of 3-and 4-species mixed infections has any significance.

The 3 species of avian hosts currently known for A. quiscali, white-throated sparrows, common grackles, and red-winged blackbirds have broadly overlapping breeding distributions across boreal latitudes of southern Canada (Godfrey, 
1976) and wintering ranges extending south across the continental U.S.A. to northern Mexico. Thus, it is possible that transmission of this parasite could occur in either or both the wintering and breeding ranges of these avian hosts, as determined by the availability of suitable (presumably) arthropod intermediate hosts. The presence of fully gravid specimens in birds that have recently arrived on the breeding grounds cannot be taken as definitive evidence that the parasites were acquired on the wintering grounds. If the rate of development in the definitive host is relatively slow, the infection could occur on the breeding grounds prior to departure for the wintering grounds, and full development of gravid cestodes might not occur until the following spring, when the birds return to their breeding grounds. The same can be said for the 3 species of digeneans, all of which could have been acquired by $Z$. albicollis either on the summer breeding grounds in Ontario where we collected them, or on the wintering grounds, where $B$. nan$u m$ and $Z$. alveyi have been reported previously in white-throated sparrows.

D.R.B. acknowledges support by operating grant A7696 from the Natural Sciences and Engineering Council of Canada (NSERC); A.H. acknowledges support by NSERC operating grant A0898 to J. B. Falls. Bruce Falls, Sherwin Desser, Rob DeVoogd, Christene Hubbard, and Duane Lundy are acknowledged for their assistance during the course of this study.

\section{LITERATURE CITED}

Denton, J. F., AND E. E. Byrd. 1951. The helminth parasites of birds, III: Dicrocoeliid trematodes from North American birds. Proceedings of the U.S. National Museum 102(3274): 157-202.

ELLIS, C. J. 1963. Trematodes of passerine birds from Chickasaw County, Iowa. Proceedings of the Iowa Academy of Science 70: 486-492.

Falls, J. B. 1969. Functions of territorial song in the white-throated sparrow. In Bird vocalisations, $\mathrm{R}$. A. Hinde (ed.). Cambridge University Press, Cambridge, p. 207-232.

Ficken, R. W., M. S. Ficken, and J. P. Hailman. 1978. Differential aggression in genetically different morphs of the white-throated sparrow ( $\mathrm{Zo}-$ notrichia albicollis). Zeitschrift für Tierpsychologie 46: 43-57.

GODFREY, W. E. 1976. The birds of Canada. National Museum of Canada Bulletin Number 203. National Museum of Canada, Ottawa, $428 \mathrm{p}$.

Hailman, J. P. 1975. Analysis of aggression in whitethroated sparrow types of different proportions. Bird-Banding 46: 236-240.
Hodasi, J. K. M. 1963. Helminths from Manitoba birds. Canadian Journal of Zoology 41: 1227-1231.

Jewer, D. D., AND W. Threlfall. 1978. Parasites of the fox sparrow (Passerella iliaca) and northern waterthrush (Seiurus noveboracensis) in Newfoundland, Canada. Proceedings of the Helminthological Society of Washington 45: 270-272.

KinsElla, J. M. 1974. Helminth fauna of the Florida scrub jay: Host and ecological relationships. Proceedings of the Helminthological Society of Washington 41: $127-130$.

Knapton, R. W., R. V. Cartar, and J. B. Falls. 1984. A comparison of breeding ecology and reproductive success between morphs of the whitethroated sparrow. Wilson Bulletin 96: 60-71.

- AND J. B. FAlls. 1982. Polymorphism in the white-throated sparrow: Habitat occupancy and nest-site selection. Canadian Journal of Zoology 60: 452-459.

$\longrightarrow$, AND —. 1983. Differences in parental contribution among pair types in the polymorphic white-throated sparrow. Canadian Journal of Zoology 61: 1288-1292.

KoPACHENA, J. 1992. Behavioural correlates of plumage polymorphism and post-fledging parental care in the white-throated sparrow, Zonotrichia albicollis. Ph.D. Thesis. University of Toronto, Toronto, Canada, $244 \mathrm{p}$.

LOWTHER, J. K., AND J. B. FALLS. 1968. White-throated sparrow. In Life histories of North American cardinals, buntings, towhees, finches, sparrows and allies. Part 3, O. L. Austin, Jr. (ed.). U.S. National Museum Bulletin 337, Washington, D.C., p. 1364 1392.

MARIAUX, J. 1991. Cestodes of birds from the Ivory Coast. Species of the genus Anonchotaenia Cohn, 1900. Systematic Parasitology 20: 109-120.

RausCh, R. L., AND B. B. Morgan. 1947. The genus Anonchotaenia (Cestoda: Dilepididae) from North American birds, with the description of a new species. Transactions of the American Microscopical Society 66: 203-211.

SCHMIDT, G. D. 1986. CRC handbook of tapeworm identification. CRC Press, Boca Raton, Florida, $675 \mathrm{p}$.

- , AND L. S. RoberTs. 1989. Foundations of parasitology, 4th ed. Times Mirror/Mosby College Publishing Company, St. Louis, Missouri, 750 p.

SCHWABL, H., M. RAMENOFSKy, I. SCHWABL-BENZINGER, D. S. FARNER, AND J. C. WINGFIELD. 1988. Social status, circulating levels of hormones, and competition for food in winter flocks of the whitethroated sparrow. Behaviour 107: 107-121.

Stanley, J. G., and F. C. Rabalais. 1971. Helminth parasites of red-winged blackbird, Agelaius phoeniceus, and common grackle, Quiscalus quiscalus in northwestern Ohio. Ohio Journal of Science 71: 302-303.

THORNEYCROFT, H. B. 1976. A cytogenetic study of the white-throated sparrow, Zonotrichia albicollis (Gmelin). Evolution 29: 611-621.

Watt, D. J., C. J. RALPH, AND C. T. Atkinson. 1984. The role of plumage dimorphism in dominance relationships of the white-throated sparrow. Auk 101: $110-120$. 